\title{
Partial eruption of teeth in the red fox Vulpes vulpes
}

\author{
Elwira SZUMA
}

\begin{abstract}
Szuma E. 1997. Partial eruption of teeth in the red fox Vulpes vulpes. Acta Theriologica 42: 253-258.

Six cases of partial eruption, including $\mathrm{C}^{1}(n=4), \mathrm{P}_{3}(n=1)$ and $\mathrm{M}_{1}(n=1)$, were recorded among 855 skulls of the red fox Vulpes vulpes (Linnaeus, 1758) from Poland. The reason for these hinderings of dental eruption was probably canine distemper infection suffered during infancy or the influence of some local factors, eg formation of a dentigerous cyst.

Mammal Research Institute, Polish Academy of Sciences, 17-230 Białowieża, Poland; e-mail: eszuma@bison.zbs.bialowieza.pl
\end{abstract}

Key words: Vulpes vulpes, teeth, partial eruption, canine distemper infection, dentigerous cyst

\section{Introduction}

A hindering of a tooth development, so-called retention, is an anomaly resulting from some disturbances within the process of dental formation and eruption. This abnormality may take two basic forms: (1) dental impaction, when a tooth development is suddenly broken and the whole tooth remains in the bone, (2) partial eruption, when a tooth erupts from the bone, but not entirely (Hillson 1986).

Dental impaction is frequently described and investigated together with other cases of congenital oligodonty. However, the differentiation between dental impaction and the remaining forms of oligodonty usually made through a radiographic examination, is not always fully objective. This is probably so because the unerupted tooth resorbs completely with time (Hillson 1986, Cawson 1991). Incomplete eruption of teeth in foxes has never been registered in the extensive literature on dental variations in this species (eg Döcke 1959, van Bree and Sinkeldam 1969, Rantanen and Pulliainen 1970, Pavlinov 1975, Ansorge 1993).

The aim of this paper is to provide a characterization of cases of partial dental eruption in foxes and to discuss the etiology of this phenomenon.

\section{Material and methods}

Cases of partial dental eruption were recorded among 855 skulls of the red fox Vulpes vulpes (Linnaeus, 1758) gathered on the territory of Poland between 1927 and 1987. These skulls come from 
the collection of the Mammal Research Institute, Polish Academy of Sciences in Białowieża (MRI) and the Institute of Systematics and Evolution of Animals, Polish Academy of Sciences in Cracow (ISEA).

The longest distance (measured on the buccal side) between the basalmost (adjoining the alveolar edge) and the occlusalmost points of the crown was adopted as the height of the crown of a tooth hindered in its development. The age of the animals was estimated by intensity of abrasion of the occlusal surfaces of the upper incisors, the advancement of ossification of the suture between the basioccipital and basisphenoid (Harris 1978), and the date when the animal was shot. All the individuals with underdeveloped teeth were aged between 7 and 12 months.

\section{Description}

Specimen MRI 353, subadult male, Białowieża: Incomplete eruption of the left $\mathrm{C}^{1}$. The tooth erupted to the height of $13.6 \mathrm{~mm}$, whereas its right counterpart reached $22.1 \mathrm{~mm}$ above the alveolus. Position of the left $\mathrm{C}^{1}$ in the tooth-row shows a distal displacement. The alveolus of fully erupted right $\mathrm{C}^{1}$, in its mesial part is directly adjacent to the suture between the maxilla and premaxilla, whereas the mesial edge of the left alveolus of $\mathrm{C}^{1}$ is retracted from the suture by $4.6 \mathrm{~mm}$. The left $\mathrm{P}^{1}$ is lacking, and the remaining alveolus is partially filled with bony tissue. Probably the delayed eruption of the left $\mathrm{C}^{1}$ untimely caused the loss of its distal neighbour.

Specimen MRI 2705, subadult male, Lubartów (Fig. 1): The teeth are heavily worn. The canines, except the left $\mathrm{C}^{1}$, fractured at the foundations of the crowns. Complete break-offs of the crowns or very strong abrasions are observed within the lower premolars. Such a drastic destruction of dentition is a result of a displacement from the suture between the maxilla and premaxilla of both upper tooth-rows, and some squeezing of the premolars. The observed abnormalities in the position of cheek teeth are comparable with the effects of forceps occlusion. The fact that only the left $\mathrm{C}^{1}$ did not undergo any abrasion or break-off stems from the incorrect growth direction of the tooth crown, as well as its incomplete eruption. During development the tooth was turned $180^{\circ}$. The crown is $10.0 \mathrm{~mm}$ above the alveolus, and its cusp inclines towards $\mathrm{I}^{3}$.

Specimen MRI 97387, subadult male, Pisz (Fig. 2): The right $\mathrm{P}_{3}$ is lacking. A slight gap within the bony tissue, an aperture, is visible from above. Only the cusp of the eoconid emerges through. The cusp of the right $\mathrm{P}_{3}$ reaches $1.0 \mathrm{~mm}$ above the alveolus from the buccal side, and $0.7 \mathrm{~mm}$ from the lingual side.

Specimen MRI 108007, juvenile female, Białowieża: Retention of the left $\mathrm{C}^{1}$. The crown of the tooth protrudes $7.5 \mathrm{~mm}$ from the alveolus, and displays no signs of wear.

Specimen ISEA 3461/67, subadult male, Sucha Beskidzka (Fig. 3): Partial eruption of the right $\mathrm{C}^{1}$. Its crown protrudes merely $4.4 \mathrm{~mm}$ above the edge of the alveolus.

Specimen ISEA 3709/67, juvenile male, Torun (Fig. 4): Obstruction of the left $\mathrm{M}_{1}$ eruption. Only the distal part of the molar completely erupted above the alveolus. The mesial part of the tooth, together with the paraconid, are dipped in 
the mandible and covered by bony tissue. In the widely opened aperture of the partially erupted $\mathrm{M}_{1}$, the metaconid and paraconid are visible from above. Both the appearance of the mandible around $\mathrm{M}_{1}$ and of the tissue of the tooth indicate a pathological process. It affected the buccal side of the left $\mathrm{M}_{1}$ and the adjacent bone. On the level of $\mathrm{M}_{1}$, the exterior side of the mandibular bone shows an explicit swelling and broadening. Below the entoconid in the mandible there is a visible basin with walls that are porous in structure. Around the alveolus of the partially erupted $\mathrm{M}_{1}$ a narrow edge emerges giving the impression of a step between the lower interior part of the bone with the tooth in the middle, and the slightly higher surrounding bony tissue of the mandible. Moreover, the left $\mathrm{M}_{1}$ is a little displaced to the front. Between the posterior edge of the $\mathrm{M}_{1}$ talonid and the mesial side of the $\mathrm{M}_{2}$ crown there is a gap about $2.5 \mathrm{~mm}$ long.

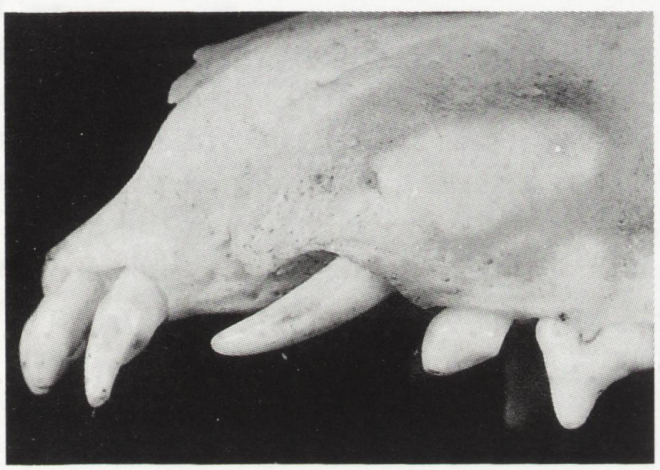

Fig. 1. Partial eruption and rotation of the left $\mathrm{C}^{1}$ in red fox MRI 2705 (lateral view).

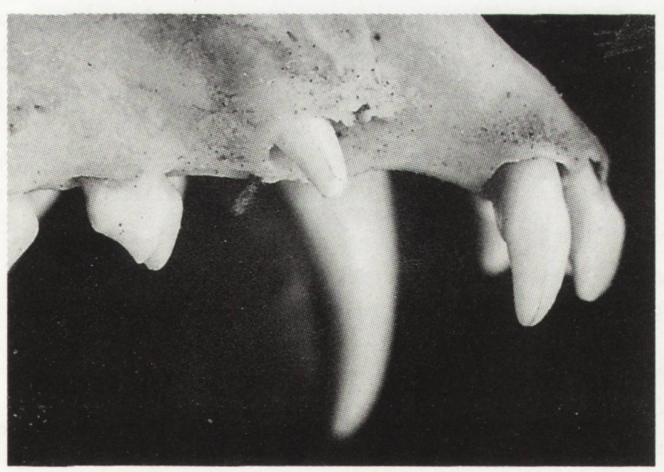

Fig. 3. Partial eruption of the right $\mathrm{C}^{1}$ in red fox ISEA 3461/67 (lateral view).

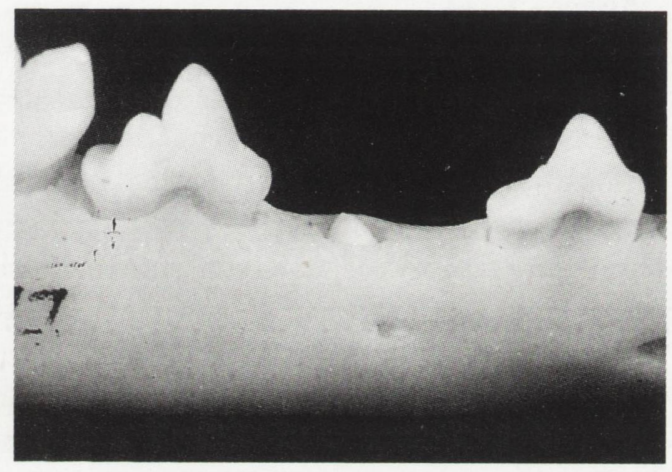

Fig. 2. Partial eruption of the right $\mathrm{P}_{3}$ in red fox MRI 97387 (lateral view).

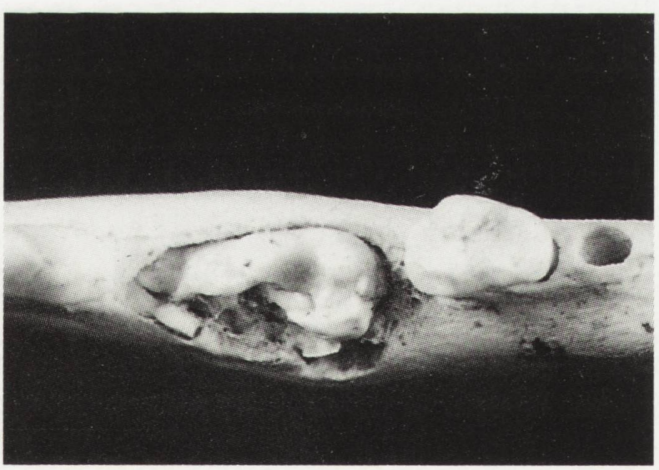

Fig. 4. Incomplete eruption of the left $\mathrm{M}_{1}$ in red fox ISEA 3709/67 (occlusal view). 


\section{Discussion}

Simultaneous hindering of the eruption of many teeth, or the whole dentition, both in humans and the remaining mammals, is found to be extremely rare. Partial eruptions of single teeth are observed significantly more often (Cawson 1991). The described cases of hindered eruptions in permanent dentition of six foxes also concern single teeth.

It has been reported so far that partial eruption of teeth in wild predators concerns mainly canines and premolars. For example, partial eruption of the right $\mathrm{C}_{1}$ in the North-American badger Taxidea taxus (Long and Long 1965), incomplete eruption of the left $C_{1}$ in the fisher Martes pennanti (Herán 1970), hindering of both $\mathrm{P}^{1} \mathrm{~s}$ in the wolf Canis lupus (Buchalczyk et al. 1981), as well as the partial eruption of the left $\mathrm{P}^{3}$, right $\mathrm{M}_{1}$, and right $\mathrm{dC}_{1}$ in the pine marten Martes martes (Wolsan 1984).

From among the six cases of partial eruption of teeth in the fox, as many as four considered canines. In all the cases the canines had had enough space to emerge, the placement of the partially erupted teeth had been correct, and no signs of cysts or other pathological changes were observed. None of the local factors suggested by Cawson (1991), which could have caused a distortion in the dental eruption (eg loss of space in the tooth-row, improper position of the bud, dental impaction, appearance of additional teeth, development of cysts or retention of deciduous teeth) seems to explain the partial eruption of canines in foxes. Therefore, it can be assumed that these anomalies are caused by systemic disorders.

Canine distemper virus is one of the most important pathogens of carnivores. In Spain, this virus is frequently identified as a cause of death or disease in dogs (Nieto et al. 1987 cited in López-Peña et al. 1994), ferrets Mustela putorius-furo, and mink Mustela vison (Nieto et al. 1992 cited in López-Peña et al. 1994). The most recent reports confirm the wide spread of canine distemper infection also in the fox (López-Peña et al. 1994). The investigations of many developmental dental anomalies (eg dental impaction, partial eruption, enamel hypoplasia, and dentin hypoplasia) in Tanzanian tropical mixed-breed dogs indicate that the probable cause of them is canine distemper infection suffered in infancy (Bittegeko et al. 1995). The authors state that dental developmental anomalies in dogs caused by an earlier experience of a viral infection concern various teeth but especially the canines.

Concerning the sequence of permanent dentition eruption (defined as the first appearance of a tooth in the gum), the upper canine teeth emerge at the age of 18 or 19 weeks. They are immediately followed by the third lower premolars (the 19th to 21st week). The process of permanent dentition eruption is completed between the 24th and 27th weeks, ie at the moment when the last $\mathrm{M}_{3}$ emerges. Towards the end of the sixth month of the fox's life, the animal possesses fully developed permanent dentition (Linhart 1968). Undoubtedly, the duration of the disease suffered by the animal is the deciding factor as to which tooth family shall be burdened with developmental anomalies. 
In the case of a 10-month-old female Tanzanian tropical mixed-breed dog described by Bittegeko et al. (1995), the hindering of the left $\mathrm{C}^{1}$ eruption as well as the dental impaction of the right $\mathrm{C}_{1}$ and right $\mathrm{P}_{4}$ were caused by a typical clinical distemper infection at the age of 2 months. In dogs, germs of permanent canine teeth and incisors appear as early as in the 8th week. One should expect that distemper infection in this or later periods of dental development shall cause dental abnormalities (Bodingbauer 1960). Partial eruption of canine teeth in the individuals marked MRI 353, MRI 2705, MRI 108007, ISEA 3461/67 and the right $\mathrm{P}_{3}$ in the individual marked MRI 97387 may have resulted from canine distemper infection suffered in infancy or earlier.

The causes of the partial eruption of the left $\mathrm{M}_{1}$ in ISEA 3461/67 seem to be of a completely different nature than those in the examined individuals with the hindered development of the canines and the premolar. This case, except the hindered eruption, shows a swelling of the mandible, presence of an additional bony stroma around the alveolus, a depression in the bony tissue, changes in the structure of the bony tissue and the tooth on the buccal side as well as a displacement to the buccal and mesial direction. Cawson (1991) states that the presence and development of a cyst is a frequent cause of a chronic swelling of the mandible. The appearance of the mandible suggests that the cyst was probably adjacent to the neck of the root and embraced the buccal part of the molar crown. Such cysts, defined as dentigerous or follicular cysts, are formed as a result of a division between the internal enamel epithelium covering the enamel and the external enamel epithelium. Formation and development of a dentigerous cyst may result in a hindering of tooth eruption, as well as a displacement of the attacked tooth (Cawson 1991). Hindering the eruption of the left $\mathrm{M}_{1}$ is an effect of deterrent influence of the follicular cyst formed in the course of tooth development.

Partial eruption of teeth covered $0.7 \%$ of the examined fox population in Poland ( $n=855)$, whereas the dental impaction, as well as partial eruption, in the population of the Tanzanian tropical mixed-breed $\operatorname{dogs}(n=450)$ occurred with the frequency of $0.4 \%$ (Bittegeko et al. 1995). It could be that the preventive vaccination of the dogs against canine distemper infection reduces the risk of their falling ill, thus limiting one of the significant factors causing dental developmental abnormalities.

Aknowledgements: I wish to thank Professors Z. Pucek, M. Wolsan and W. Bogdanowicz for critical reading of an earlier version of this paper. I also thank Professor K. Kowalski, from the Institute of Systematic and Evolution of Animals PAS, Cracow, for making the skulls available for this study.

\section{References}

Ansorge H. 1993. Dentalverhältnisse des Rotfuchses Vulpes vulpes in der Oberlausitz. Beiträge zur Jagd- und Wildforschung 18: 71-78.

Bittegeko S. B. P. R., Arnbjerg J., Nkya R. and Tevik A. 1995. Multiple dental developmental abnormalities following canine distemper infection. Journal of the American Animal Hospital Association 31: 42-45. 
Bodingbauer J. 1960. Retention of teeth in dogs as a sequel to distemper infection. The Veterinary Record 72: 636-638.

Bree P. J. H. van and Sinkeldam E. J. 1969. Anomalies in the dentition of the fox, Vulpes vulpes (Linnaeus, 1758), from continental western Europe. Bijdragen tot de Dierkunde 39: 3-5.

Buchalczyk T., Dynowski J. and Szteyn S. 1981. Variations in number of teeth and asymetry of the skull in the wolf. Acta Theriologica 26: 23-30.

Cawson R. A. 1991. Essentials of dental surgery and pathology. Churchill Livingstone, Edinburg.

Döcke F. 1959. Zahn- und Bissanomalien beim Wild- und Farmfuchs. Archiv für Tierzucht 2: 130-161.

Harris S. 1978. Age determination in red fox (Vulpes vulpes) - an evaluation of technique efficiency as applied to a sample of suburban foxes. Journal of Zoology, London 184: 91-117.

Heráň I. 1970. Anomalies in the position of lower teeth in the fisher Martes pennanti Erxl. (Mammalia; Mustelidae). Canadian Journal of Zoology 48: 1465.

Hillson S. 1986. Cambridge manuals in archaeology. [In: Teeth. D. Brothwell, B. Cunliffe, S. Fleming and P. Fowler, eds]. Cambridge University Press, Cambridge: 1-376.

Linhart S. B. 1968. Dentition and pelage in the juvenile red fox (Vulpes vulpes). Journal of Mammalogy 49: 526-528.

Long C. A. and Long C. F. 1965. Dental abnormalities in North American badgers, genus Taxidea. Transactions Kansas Academy of Science 68: 145-155.

López-Peña M., Quiroga M. I., Vázquez S. and Nieto J. M. 1994. Detection of canine distemper viral antigen in foxes (Vulpes vulpes) in Northwestern Spain. Journal of Wildlife Diseases 30: 95-98.

Pavlinov I. Ya. 1975. Tooth anomalies in some Canidae. Acta Theriologica 20: 507-519.

Rantanen A. V. and Pulliainen E. 1970. Dental conditions of wild red foxes (Vulpes vulpes L.) in northeastern Lapland. Annales Zoologici Fennici 7: 290-294.

Wolsan M. 1984. Dental abnormalities in the pine marten Martes martes (L.) (Carnivora, Mustelidae) from Poland. Zoologische Anzeiger 213: 119-127.

Received 23 December 1996, accepted 16 June 1997. 